Onomastica Slavogermanica

XXXI

Wrocław 2019

DOI: $10.19195 / 0474-1471.31 .7$

STANISŁAWA SOCHACKA

Opole

\title{
Przestrzeń miejska międzywojennego Opola z perspektywy nazw własnych
}

Słowa kluczowe: chrematonimia miasta, rodzaje chrematonimów, motywacja, struktura

Na ulicach słyszysz tylko przeważnie niemiecką mowę, napisy na sklepach są przeważnie niemieckie, w hotelach i restauracjach uwijają się kelnerzy Niemcy. Ale zajrzyj tu w piątek, kiedy na rynku odbywają się tygodniowe targi, zajrzyj, a serce gwałtownie kołatać ci w piersi zacznie, gdy wspomnisz, że siedem wieków już upłynęło, jak to miasto i ta ziemia oderwane zostały od pnia wspólnego.

S. Bełza, Na Ślasku Polskim (wrażenia i spostrzeżenia), Kraków 1890, s. 92.

\section{Uwagi ogólne}

Stanisław Bełza (1849-1928), warszawski adwokat, pisarz, podróżnik i działacz kulturalny na Śląsku, wędrując ulicami Opola, z zadumą i wzruszeniem wczytywał się w napisy na witrynach i szyldach sklepowych, na których widniały także polskojęzyczne nazwy. Nie były one dominujące, ale tworzy ważny komponent przestrzeni językowej i społecznej miasta. Bogatym źródłem wiedzy o nazewnictwie miejskim Opola, a ściślej chrematonimii, są niemieckie księgi adresowe $^{1}$, rejestrujące nazwy urzędów, instytucji, fabryk, obiektów handlowych

\footnotetext{
${ }^{1}$ Por. Adressbuch der Regierungs-Hauptstadt Oppeln 1902, 1909, 1926, 1937.
} 
różnych branż wraz z lokalizacją, imionami i nazwiskami właścicieli lub dzierżawców. Z tymi zabytkami miało styczność wielu badaczy, między innymi redaktorzy nowo wydanej monografii Opola, którzy wykorzystywali zapisane tam nazwy miejskie do ilustracji różnych wątków swych rozważań2 ${ }^{2}$

Autorce niniejszego tekstu słuszne wydawało się zrekonstruowanie przestrzennego społecznego i kulturowego wizerunku miasta na podstawie materiału chrematonimicznego. Rozliczne funkcje, jakie pełniły nazwy dawnego Opola, stawiają je wysoko w procesie komunikacji językowej i społecznej. Odzwierciedlają zarówno postęp cywilizacyjny, jak i tendencje nazewnicze miasta. We współczesnych badaniach konfrontatywnych brakuje prac zawierających całościowe opisy diachronicznych i synchronicznych nazw poszczególnych miast.

Szukając odpowiedzi na pytanie, o czym mówią dawne chrematonimy Opola, nie trudno zauważyć, jak w jego obrębie sytuował się ,,pierwiastek polskiej duchowości". W ciągu wieków kultura polska na Śląsku poniosła olbrzymie straty spowodowane tym, co zdefiniowano jako niebędące pochodzenia niemieckiego. Dlatego pisząc o Opolu — starym książęcym grodzie piastowskim, mieście o etnicznych i lokalnych społecznościach — nie można pominąć jego wielowiekowej i skomplikowanej historii, przedstawiając ją w wielkim skrócie ${ }^{3}$.

Badania archeologiczne prowadzone w najstarszej przedlokacyjnej części miasta wskazują X wiek jako czas powstania na wyspie odrzańskiej, zwanej Ostrówkiem, grodu — siedziby władców piastowskich z linii opolsko-raciborskiej. Ich protoplastą stał się Mieszko Plątonogi, nazywany też Laskonogim. Ostatnim księciem z rodu Piastów był Jan Dobry (zmarł w 1532 roku), który nie pozostawił swojego następcy. Wraz z jego śmiercią czasy świetności miasta minęły bezpowrotnie, i to na wiele wieków. Księstwo opolskie przeszło we władanie czeskich Habsburgów, aby w 1742 roku znaleźć się w granicach państwa pruskiego. W 1816 roku Opole zostało stolicą nowo utworzonej rejencji opolskiej, zwanej początkowo górnośląską. Okres pruski był dla rozwoju miasta korzystny. Z rzemieślniczego miasteczka Opole przekształciło się w ośrodek przemysłowy z cementowniami, gazownią miejską, elektrownią, węzłem kolejowym, portem na Odrze. Granice miasta zostały poszerzone poprzez wyburzenie murów obronnych i bram miejskich oraz włączenie peryferyjnych przedmieść i wsi. Od drugiej połowy XIX wieku nie ustawały konflikty i spory polityczne między Polską a Niemcami o przynależność regionu, co w konsekwencji doprowadziło do wybuchu powstania i plebiscytu na Śląsku. W wyniku postanowień Rady Ambasadorów w 1922 roku Opole wraz z dużą częścią Górnego Śląska zostało po stronie niemieckiej. Polskie życie narodowe zaczęło zamierać. Elity polskie opuściły miasto. Jego odbudową zajęły się między innymi organizacja Związek Polaków w Niemczech Dzielnica I, Konsulat Generalny

${ }^{2}$ Opole. Dzieje i tradycja, red. B. Linek, K. Tarka, U. Zajączkowska, Opole 2011.

${ }^{3}$ Por. najważniejsze monografie Opola: F. Idzikowski, Opole. Dzieje miasta do 1863 roku, Opole 2002; Opole. Monografia miasta, red. W. Dziewulski, F. Hawranek, Opole 1975; Opole. Dzieje i tradycja... 
Rzeczypospolitej Polskiej, banki polskie, stowarzyszenia i organizacje polityczne, skupione wokół gazet wychodzących w Opolu 4 .

Międzywojenne Opole było ośrodkiem o specyficznym, nierzadko burzliwym, klimacie. Jego przeszłość, dziedzictwo kulturowe zespolone było z losami wielu nacji: Polaków, Niemców, Żydów, Czechów, Włochów — przedstawicieli różnych kultur i wyznań ${ }^{5}$. Dziś stolica Śląska Opolskiego liczy 126382 mieszkańców i zajmuje powierzchnię $96 \mathrm{~km}^{2}$. Przedwojenna liczba mieszkańców kształtowała się w granicach 37-50 tysięcy, a obszar miasta obejmował $30 \mathrm{~km}^{2}$.

W tych ramach czasowych przeplatają się dwa kręgi kulturowe, dwa światy - przeszły i teraźniejszy. W miejscu wczesnośredniowiecznej osady Słowian wzniesiono amfiteatr, w którym odbywa się corocznie Krajowy Festiwal Polskiej Piosenki. Z barokowo-gotyckimi kościołami, Wieżą Piastowską symbolem miasta i regionu, ratuszem wielokrotnie przebudowywanym, $\mathrm{z}$ odnowionymi gotyckimi kamieniczkami w Rynku, monumentalnymi budowlami architektonicznymi egzystują nowoczesne obiekty i miejsca zielone. Długa $\mathrm{i}$ bogata historia miasta zapisana $\mathrm{w}$ nazewnictwie miejskim pozwala zbliżyć się choć trochę do jego atmosfery. Wśród przykładów nazewniczych pozwalających na opis i charakterystykę onomastycznego obrazu miasta znajdują się nazwy:

— instytucji i urzędów miejskich i państwowych,

— obiektów związanych ze służbą zdrowia,

- obiektów przeznaczonych do obsługi ruchu turystycznego,

— lokalnych miejsc rozrywki i wypoczynku,

— obiektów handlowych i przemysłowych,

— obiektów dotyczących kultury duchownej i materialnej.

Dysponując obcojęzycznym (mieszanym) materiałem onimicznym, analizę nazw oparto na umownym kryterium pozajęzykowym (branżowym). Wiadomo, że obecnie prowadzone są dyskusje metodologiczne na temat typologii nazewnictwa miejskiego (urbanonimii i chrematonimii), proponujące różne kryteria podziału i nową terminologię 6 .

Głównym celem i przedmiotem niniejszego opracowania są nazwy obiektów miejskich i próba ich interpretacji w kontekście historycznym, bez nazw ulic, dzielnic, które zostały już opracowane?

\footnotetext{
${ }^{4}$ M. Masnyk, Polski ruch narodowy w Opolu do 1939 roku, [w:] Opole. Dzieje i tradycja...,
} s. 257.

${ }^{5}$ Zob. Opolanie, [w:] Opole. Dzieje i tradycja..., s. 339-370.

${ }^{6}$ A. Siwiec, W sprawie nazw obiektów handlowych: miejsce $w$ klasyfikacji onomastycznej, ustalenia typologiczne, terminologia, [w:] Manuscula linquistica: in honorem Alexandrae Cieślikowa oblata, red. K. Rymut, K. Skowronek, Kraków 2006, s. 423-436.

${ }^{7}$ M. Choroś, Ł. Jarczak, Ludzie i historia w nazwach ulic Opola, Opole 2010. 


\section{Obiekty będące siedzibą instytucji miejskich i państwowych}

Czasy pruskie wraz z rozwojem administracyjnym miasta przyniosły nowe gmachy przeznaczone dla licznie powstających urzędów i instytucji. Początkowo zajmowały one istniejące już budynki, na przykład prywatne kamienice lub zabudowania pozostałe po kasacji zgromadzeń zakonnych. Nawet Zamek Piastowski, sięgający czasów Kazimierza I, użytkowano jako gmach rejencji opolskiej. W latach 1928-1931 został on zburzony, a w tym miejscu powstał nowy obiekt architektoniczny: Regierung Oppeln, obecnie mieści się tu Urząd Wojewódzki.

Proces rozwojowy miasta jako centrum zarządzania przybierał na sile. $\mathrm{Z}$ roku na rok przybywało nowych budowli publicznych, zwłaszcza rozbudowywano infrastrukturę. Lawinowo napływająca fala niemieckich urzędników dała asumpt do nazwania Opola „miastem urzędników”. Organy administracji miejskiej i państwowej reprezentowały między innymi: Stadtverwaltung (Urząd Miejski), Regierung Oppeln (Rejencja Opolska), Amtsgericht (Urząd Sądowy), Postamt (Urząd Pocztowy), Finanzamt (Urząd Skarbowy), Kulturamt (Urząd do Spraw Kultury), Hauptzollamt (Główny Urząd Celny), Oberversicherungsamt (Główny Urząd Ubezpieczeniowy), Versorgungamt (Urząd Zaopatrzenia), Preusisches Katasteramt (Pruski Urząd Katastralny), Staatliches Polizeiverwaltung (Państwowy Urząd Policji), Reichsbahndirektion (Dyrekcja Kolei Rzeszy), Staatliches Gesundheitsamt (Państwowy Wydział Zdrowia), Provinzialschulkolegium (Prowincjonalne Kolegium Szkolne), Hochbauamt (Urząd Budownictwa Nadziemnego), Wasserbauamt (Urząd do Spraw Budownictwa Wodnego), Minderheitsamt (Urząd do Spraw Mniejszości). Po 1923 roku nakazem władz miejskich zintensyfikowano starania o dalszy rozwój Opola. Wyrazem wzrostu gospodarczego była ożywiona działalność instytucji finansowo-kredy towych i bankowych. Ich funkcjonowanie było skorelowane $\mathrm{z}$ rozbudową miasta, zwłaszcza $\mathrm{z}$ budownictwem mieszkaniowym. Świadczą o tym ich nazwy: Oberschlesische Beamtenbank (Górnośląski Bank Urzędniczy), Deutsche Bank und Disconto-Gesselschaft (Bank Niemiecki i Stowarzyszenie Dyskontowe), Dresdener Bank, Filiale Oppeln (Bank Drezdeński, Filia Opole), Bank für Dt. Industrie-Obligationen (Bank Niemieckich Obligacji Przemysłowych), Gewerbebank (Bank Przemysłowy), Prowinz-Genossenschaftsbank (Prowincjonalny Bank Spółdzielczy), Reichsbank (Bank Rzeszy). Oprócz państwowych i prywatnych instytucji bankowych w latach dwudziestych XX wieku powstały miejska i powiatowa kasa oszczędnościowo-pożyczkowa Stadtspar und Girokasse, Kreisspar und Girokasse.

Wśród dwunastu banków w księdze adresowej Opola z 1937 roku wymieniono trzy instytucje polskie: Bank Rolników, Bank Ludowy i Spótdzielnię Zaopatrzenia i Zbytu ,Rolnik”, w których polscy chłopi z okolicznych wsi zbywali na korzystnych warunkach płody rolne i zaopatrywali się w artykuły gospodarcze

${ }^{8}$ W. Kaczorowski, Opole jako centralny ośrodek zarządzania na Górnym Śląsu (w świetle opracowania nadburmistrza dra Augusta Neugebauera), Almanach Miejski „Opolanin” 2000, s. 34. 
i narzędzia do produkcji rolnej. Wszystkie trzy instytucje wszechstronnie wspierały narodową działalność Polaków, udzielając pomocy finansowej i pomieszczeń. Bank Rolników prowadzi swoją działalność do dziś w tym samym miejscu.

Nazwy instytucjonalne tworzą we wszystkich miastach fundamentalny korpus. Zarówno nazwy niemieckie, jak i polskie z formalnego i semantycznego punktu widzenia są sobie bliskie. Reprezentują powszechnie funkcjonujący w komunikacji światowej model dostarczający informacji o specjalizacji urzędów $\mathrm{i}$ ich działalności praktyczno-usługowej. Są to z reguły formy wielowyrazowe, pozbawione elementów reklamowych, łączące w sobie regularnie funkcję identyfikacyjną (nazewniczą) z funkcją oznaczającą (sygnifikacyjną), typową dla apelatywów. Są one łatwo przetłumaczalne na języki obce.

\section{Obiekty związane ze służbą zdrowia}

Oprócz obowiązku stworzenia ludności odpowiednich warunków egzystencji i prawidłowego rozwoju życia społecznego podstawową funkcją publiczną miasta była ochrona zdrowia i opieka społeczna. Rozbudowa życia gospodarczego miasta i wzrost ludności pociągały za sobą potrzebę rozwoju tej sfery usług w kilku formach infrastrukturalnych, takich jak: szpitale, kasy chorych, izby chorych, prywatne gabinety lekarskie, apteki.

\subsection{Szpitale i gabinety prywatne}

Najważniejszymi placówkami służby zdrowia od dawna były szpitale. Władze Opola długo nie były w stanie wybudować nowoczesnego szpitala. Średniowieczne szpitale (nie tylko w Opolu) pełniły funkcję przytułków. W tym miejscu warto wyjaśnić, że w XV wieku słowo szpital (niem. Hospital, Spital) oznaczało 'przytułek dla ubogich', co miało związek z łac. domus hospitalis 'gospoda, dom gościnny'.

Pierwszy opolski szpital (przytułek) zbudowany został w 1421 roku ze środków fundacji księcia (biskupa) Jana Kropidły, syna księcia Bolesława III, przy kościele św. Aleksego - dziś kaplica, przy ul. Szpitalnej (por. zapisy: Spitalna - 1582, na Spitalski ulicy - 1589) ${ }^{9}$.

Nowy szpital otwarto w 1851 roku w budynku klasztoru dominikańskiego (dziś siedziba Uniwersytetu Opolskiego), przy kaplicy św. Wojciecha ${ }^{10}$. Początkowo był on wyposażony tylko w oddział wewnętrzny. W 1915 roku rozpoczęto budowę oddziału chirurgicznego $\mathrm{w}$ innym miejscu. Obiekt został oddany do użytku w 1918 roku. Trzeci obiekt szpitalny powstał w 1934 roku. Była to klinika położnicza, a dla zamożnych mieszkańców otwarto w tym czasie klinikę prywat-

\footnotetext{
${ }^{9}$ M. Choroś, Ł. Jarczak, op. cit., s. 121.

10 J. Filipczak, Zabytki mówia, [w:] Opole. Dzieje i tradycja..., s. 202.
} 
ną. Wymienione placówki medyczne miały oficjalne nazwy niemieckie: Sankt Alexi - Hospital, Sankt Adalbert - Hospital Altbau, Sankt Adalbert - Hospital Neubau, Frauenklinik, Priwatklinik.

Ważne znaczenie dla opolan miała prywatna służba zdrowia, obejmująca 37 gabinetów różnych specjalności. Najwięcej było internistów, a ponadto usługi świadczyli: chirurdzy, pulmonolodzy, laryngolodzy, ginekolodzy, neurolodzy, pediatrzy i sporo dentystów. Na tle niemieckiego nazewnictwa swą odrębność językową akcentowały polsko brzmiące nazwiska praktykujących lekarzy: Paul Goretzky, Werner Kuczora, Johannes Kwoczek ${ }^{11}$, Ernst Lapczyna, Edmund Smykalla, Hugo Pieschkalla. Nie oznacza to, że byli oni Polakami. W celu utrzymania warunków higienicznych na odpowiednim poziomie magistrat wybudował łaźnię miejską, w której znajdowały się wanny i natryski (Städtische Warmbadeanstalt). Funkcjonowała ona jeszcze długo po 1945 roku.

W zasięgu działania administracji miejskiej były też Przytułek dla Sierot (Katholisches Waisenhaus), Dom Dziecka (Kinderheim) oraz Izba Chorych (Krankenstation). Podsumowując rozważania o nazwach opolskich szpitali, możemy dostrzec te same zmiany, jakim podlegała ta grupa nazw w innych miastach ${ }^{12}$.

W najstarszym okresie w krajach europejskich obiekty należące do kościoła określane były poprzez nazwy patrocinium: kościót > szpital św. Wojciecha; kościót > szpital św. Aleksego. W wypadku obiektów należących do miasta lub prywatnych właścicieli ich nazwy miały deskrypcyjny charakter (w języku niemieckim były to composita), wskazujące na typ placówki, jej przeznaczenie lub przynależność: Frauenklinik (Klinika Położnicza), Priwatklinik (Klinika Prywatna). Integralną częścią lecznictwa była sieć aptek.

\subsection{Apteki}

Pierwsze wzmianki o istnieniu i funkcjonowaniu w mieście apteki (kramu, por. gr. apotheke 'kram, buda', apothecarius 'kupiec') pochodzą z XVI wieku. W 1564 roku Rada Miejska Opola sprzedała Józefowi „Aptekarzowi” (bez nazwiska) kram za 160 talarów. „Aptekarz” Józef, otwierając aptekę, nazwał ją Miejska (Stadt-Apotheke) ${ }^{13}$. Takie były początki najstarszej apteki w Opolu, funkcjonującej pod tą nazwą do 1945 roku.

W 1673 roku jezuici otworzyli drugą aptekę w budynku kolegium jezuickiego. Po sekularyzacji dóbr zakonnych w 1773 roku budynek i apteka przeszła na własność państwa pruskiego. Nowy jej dzierżawca, Carl Friedrich Foelkel,

${ }^{11}$ J. Kwoczek - lekarz, działacz ruchu narodowego na Śląsku; o nazwiskach opolan zob. D. Lech-Kirstein, Nazwy osobowe dziewiętnastowiecznych mieszkańców Opola (ze słownikiem etymologicznym nazwisk), Opole 2004.

12 M. Graf, Nazwy budowli i miejsc wydzielonych, [w:] Nazewnictwo geograficzne Poznania, red. Z. Zagórski, Poznań 2008, s. 567.

${ }^{13}$ W. Kaczorowski, Przywilej Apteki Miejskiej w Opolu, Almanach Miejski „Opolanin” 2003, s. $22-24$. 
połączył ją z Apteka Miejska. Apteka jezuicka występowała pod nazwą Schuleninstitut- und Gimnasialapotheke (Apteka Instytutu Szkolnego i Gimnazjum) ${ }^{14}$.

Kolejne apteki powstały w Opolu w XIX i XX wieku, a były to:

— Löwen-Apotheke (Apteka pod Lwem), założona w 1824 roku z inicjatywy władz rejencji opolskiej. Koncesję na jej prowadzenie otrzymał Heinrich Emanuel Grabowski z Głubczyc. Ulokował ją w Rynku pod nr. 1, w kamienicy z emblematem lwa, gdzie funkcjonuje do dziś pod tą samą nazwą.

— Kronen-Apotheke (Apteka pod Koroną), powstała w 1894 roku. Zgodę na jej prowadzenie otrzymał Georg Höfer z Pszczyny, gdzie kierował apteką Mohrenapotheke (Pod Murzynem). Apteka często zmieniała właścicieli, ale pod niezmienioną nazwą przetrwała do 1945 roku, kiedy to nadano jej nazwę Apteka Piastowska.

- Germania-Apotheke (Apteka Niemiecka). Koncesję na jej prowadzenie otrzymał w 1902 roku Paweł Kropiwoda, który prowadził ją do 1924 roku. Kolejnymi dzierżawcami byli: Roman Muklanowicz, Kurt Palten, Wilhelm Steiner.

- Marien-Apotheke (Apteka Mariacka). Założycielem w 1925 roku był Max Dudel. Do Opola przybył z Zabrza, gdzie kierował dwoma aptekami - Sankta Barbara i Königin Luise. Opolska apteka nawiązywała do nazwy kościoła pw. Najświętszej Marii Panny. Po 1945 roku w użyciu była nazwa Apteka Mariacka.

- Eichendorff-Apotheke (Apteka im. Eichendorffa). Jej założycielem był w 1925 roku Erich Kolars, pochodzący z Raciborza. Nazwa apteki upamiętnia nazwisko niemieckiego poety i prozaika z okresu romantyzmu (1788-1857), urodzonego pod Raciborzem. Pod tą nazwą apteka była czynna długo po wojnie.

- Nikolai-Apotheke (Apteka Mikołajska). Kierował nią w latach 1926-1941 Curt Haase. Jego następczynią została córka Loni Leinkauf. Apteka była położona przy ul. Nikolaistrasse (dziś ul. Książąt Opolskich).

Krótkie informacje historyczne o aptekach miały na celu przybliżenie procesu kształtowania się handlu środkami leczniczymi. W tym czasie w wielu państwach europejskich istniał już rozdział pomiędzy zawodem lekarza i aptekarza. Aptekarze często zmieniali swoje miejsca zamieszkania w poszukiwaniu lepszych warunków pracy. Sam system nazewniczy aptek był ustabilizowany i oparty na stereotypowych modelach.

Przedstawione nazwy opolskich aptek reprezentują cztery grupy semantyczne wskazujące na:

— właściciela (założyciela): Stadt-Ap.,

- lokalizację: Marien-Ap., Nikolai Ap.,

— tradycję historyczną i literacką: Germania-Ap., Eichendorff-Ap.,

- godła ikoniczne: Löwen-Ap., Kronen-Ap.

Popularność tego typu nazw sprawiła, że odnajdujemy je w przestrzeni innych miast śląskich, na przykład Kloster-Ap. (Gliwice), Stadt-Ap. (Mysłowice),

14 W. Brachmann, Beyträge zur Apothekengeschichte Schlesien, Würzburg 1966, s. 417. 
Germania-Ap. (Jawor), Eichendorff-Ap., Apotheke zur Kronen (Wrocław) ${ }^{15}$. Można też przyjąć, że konwencja nominacyjna aptek stała się wzorem nazw drogerii, na przykład Adler-Drogerie (Drogeria pod Orłem), Bahnhof Dr. (Drogeria Dworcowa), Central Dr. (Drogeria Centralna), Goethe Dr. (Drogeria im. Goethego), Piasten Dr. (Drogeria Piastowska), Schwanen Dr. (Drogeria pod Łabędziem), Sankt Peter-Paul Dr. (Drogeria św. Piotra i Pawła — położona w pobliżu kościoła pw. św. Apostołów Piotra i Pawła).

\section{Obsługa ruchu turystycznego - hotele}

Istotnym uzupełnieniem infrastruktury miejskiej związanej z komunikacją i obsługą ruchu turystycznego była sieć hoteli. W 1909 roku Opole było już ważnym ośrodkiem administracyjnym i znajdowało się w nim sześć hoteli. W 1937 roku przybywający do miasta turyści mieli do dyspozycji następujące oferty: Central Hotel (Hotel Centralny), Forms Hotel (Hotel Forma), Hotel Deutsches Haus (Hotel Niemiecki Dom), Huchs Hotel (Hotel Hucha), Krugs Hotel (Hotel Kruga), Hotel Weisser Schwan (Hotel Pod Białym Łabędziem), Hotel Germania (Hotel Niemcy), Hotel Stadt Breslau (Hotel Miasto Wrocław), Hotel Monopol. Najbardziej reprezentacyjnymi hotelami były: Hotel Forma i Hotel Kruga, położone w pobliżu Dworca Głównego. Charakteryzowały się one wyższym standardem, na przykład miały wodociągi, kanalizację, garaże, co było podnoszone $\mathrm{w}$ ofertach reklamowych ${ }^{16}$. Turystyką międzynarodową zajmowało się w owym czasie renomowane biuro podróży Reisebüro-Hamburg-Amerika Linie. Oceniając nazwy hoteli opolskich, widzimy, że odzwierciedlają one tendencje europejskie. Są konkretne, czytelne i komunikują, że:

- hotele mają dobre położenie: Central Hotel, Hotel Stadt Breslau,

- gwarantują swojską atmosferę i poszanowanie dla wartości rodzinnych: Hotel Deutsches Haus — podkreślają zasięg działania placówki i związek ze staroży tną historią: Hotel Germania,

- mają zagwarantowane uprawnienia (status prawny): Hotel Monopol,

- wywodzą się z pierwotnych, ikonicznych znaków firmowych tych budynków: Hotel Weisser Schwan,

— określają przynależność do właściciela, który gwarantuje wysoką jakość usług: Forms Hotel, Huchs Hotel, Krugs Hotel.

${ }^{15}$ I. Seiffert, Dolnośląskie apteki i ich nazwy w przekroju historycznym, „Onomastica Slavogermanica” 27, 2008, s. 207-233; eadem, Nazwy wrocławskich aptek - przeszłość i współczesność, [w:] Z najnowszych tendencji nazewniczych, red. R. Łobodzińska, Łask 2005, s. 83-98.

16 Por. Forms Hotel Ersten und grösstes Haus am Platze (Hotel Forma pierwszy i największy hotel na placu); Krugs Hotel Zimmer mit fliessen den Wasser Sonderzimmer für Vereine und Festlichkeiten (Hotel Kruga pokoje z bieżącą wodą specjalne pokoje dla stowarzyszeń i uroczystości). 


\section{Lokalne miejsca rozrywki i wypoczynku}

Nieodłącznym elementem pejzażu miasta i życia jego mieszkańców były kawiarnie, restauracje, gospody i tereny rekreacyjne. Restauracje i kawiarnie odgrywały podwójną rolę: oferowały klientom smaczne i niedrogie posiłki oraz były ośrodkami życia społecznego i kulturalnego. Organizowano w nich zebrania, bankiety, występy teatralne, odczyty i wystawy. Gromadziła się w nich miejscowa inteligencja, członkowie różnych towarzystw polskich i niemieckich, które nie miały własnych sal spotkań, na przykład w restauracji Hotelu Hucha organizowano zabawy dla polskiej młodzieży, a Hotel Forma w reprezentacyjnej sali przyjmował artystów i uczonych ${ }^{17}$. Latem życie społeczno-towarzyskie przenosiło się do pięknych ogródków, urządzanych na zapleczu lokali, do parków na wyspie Pasiece i wyspie Bolko. W ogródkach można było zjeść i wypić na wolnym powietrzu czy potańczyć „na deskach". Zimą opolanie szli na lodowiska do Parku Zamkowego i na wyspę Bolko.

\subsection{Kawiarnie}

Najatrakcyjniejsze kawiarnie i restauracje ulokowane były w centrum miasta i przy głównych szlakach komunikacyjnych. Od lat miejscami szczególnie przyciągającymi klientów były trzy renomowane kawiarnie-cukiernie nazywane określeniami eksponującymi nazwiska właścicieli. Jedną z najbardziej oryginalnych była Kawiarnia Malcomessa, założona w 1818 roku ${ }^{18}$, usytuowana w pięknej rokokowej kamienicy, zburzonej w czasie ostatniej wojny światowej. Jedynymi pamiątkami po tym lokalu są fotografie wnętrza oraz oryginalna łyżeczka z napisem Malcomess, zachowana w Muzeum Śląska Opolskiego. Oto nazwa kawiarni wraz z reklamą: Konditorei und Café Wilhelm Malcomess Spezialität: Feinse Torte, Gebäcke und Desserts stets Neuheiten in prima Pückler - Eisspeisen und Creme. Alle Waren sind frei von Margarine ${ }^{19}$. Jest to typowy przykład nazwy firmowej mocno osadzonej w tradycji niemieckiej. Jej reklama akcentuje nazwisko właściciela oraz rodzaj oferowanych produktów.

Konkurentami Malcomessa były dwa inne, równie renomowane, lokale: Konditorei und Café Emil Knietsch. Lokal został otwarty w 1889 roku i przyciągał tłumy klientów. Specjalnością kawiarni-cukierni były wypieki wiedeńskie Paul Gebel Konditorei und Kaffehaus. Lokal został otwarty w 1908 roku i cieszył się dużą frekwencją. Miał też dobre położenie vis-à-vis hotelu Forma i Dworca Głównego. W 1937 roku czynnych było w Opolu 16 kawiarni firmowanych na-

${ }^{17}$ W. Lesiuk, Życie polskie w Opolu w latach 1808-1918, [w:] Opole. Monografia miasta..., s. 342 .

${ }^{18}$ U. Zajączkowska, Lyżeczka Malkomessa, Almanach Miejski „Opolanin” 2000, s. 56.

19 Tłumaczenie: Cukiernia i kawiarnia Wilhelm Malkomess. Specjalność: Wspaniałe torty, wypieki i desery stale nowości na pierwszym miejscu lody Pücklera i kremy. Wszystkie towary wolne od margaryny. 
zwiskami właścicieli, wśród nich wyróżniały się nazwiska o polskiej proweniencji, na przykład Konrad Bakalla, Otto Hyttrek, Georg Zajontz, Karl Kaminsky, Paul Lopatta i inni.

Dalsza analiza nazw kawiarni pozwala wyodrębnić grupę onimów wykorzystujących wartości konotacyjne leksemów. Ich motywacje wynikają z potrzeby reklamy. Poznajmy ich nazwy:

- Café Residenz (Kawiarnia Rezydencyjna), położona w centrum. Był to wytworny lokal wybudowany w stylu rokokowym, co stawiało obiekt w jednoznacznie dobrym świetle. Celem reklamy było dotarcie do zamożnych klientów.

- Café Roland (Kawiarnia Roland). Nazwa konotująca treści literackie, nawiązująca do słynnego poematu średniowiecznego Pieśń o Rolandzie, skierowana do kręgów naukowych i literackich, skupionych w różnych towarzystwach kulturalnych.

- Schlosscafé (Kawiarnia Zamkowa). Myślą przewodnią nazwy było wskazanie atrakcyjnego miejsca w pobliżu Zamku Piastowskiego (Piastenschloss), na wyspie Pasiece, w pobliżu ogrodów zamkowych.

- Café Osten (Kawiarnia Wschodnia). Lokal był położony w części peryferyjnej miasta, nieopodal Dworca Wschodniego (Ost Banhof) — była to tak zwana nazwa orientująca.

— Tagescafé und Bestelgeschäft (Kawiarnia Dzienna z Zamówieniami) oferowała szeroki zakres usług.

Nazwy te charakteryzują się prostotą, w których człon gatunkowy jest integralną częścią właściwej nazwy. Znajduje się on bądź w prepozycji (Café Osten, Café Roland) lub w postpozycji (Tagescafé, Schlosscafé).

\subsection{Restauracje}

Przedwojenne nazwy restauracji nie są tak atrakcyjnym zbiorem. Wiele $\mathrm{z}$ nich mieściło się $\mathrm{w}$ hotelach i były określane tą samą nazwą, co jest reguła nazewniczą do dziś $\mathrm{w}$ różnych krajach świata. Takie nazwy powiązane są z sobą na zasadzie styczności przestrzennej. Łatwo to wyczytać z tablic informacyjnych i ogłoszeń reklamowych zamieszczanych w księgach adresowych, na przykład:

- Forms Hotel Bier-und Wein-Restaurant, Tanzdiele, Konzertgarten, Festsäle (Piwiarnia-Winiarnia Dansingi, Ogród Koncertowy, Sale Reprezentacyjne).

- Krugs Hotel-Restaurant Benannt gute Küche,

Eishaus-Restaurant Die am Schlossteich herrlich gelegene Terrasengaststätte Oppelns bietet allen Besuchern einem angenehmen Aufenthal ${ }^{20}$.

W drugiej grupie nazw opolskich restauracji przeważała tendencja, u której podłoża widniały imiona i nazwiska właścicieli. W ówczesnym Opolu powszechnym zainteresowaniem cieszyły się trzy tego rodzaju restauracje: Josef Drzizga

20 Tłumaczenie: Domek Lodowy — restauracja przy stawku zamkowym uroczo położona restauracja tarasowa zaprasza wszystkich odwiedzających na przyjemny pobyt. 
Weinrestaurant $($ nazw. Drzizga $=$ Drzazga), Karl Dirska Restaurant und Biergrossenhandlung (nazw. Dirska = Dzierżka: dzierżeć), Anna Stettinius, Gerhard Czempiel Feinkost-Wein-Frühstückstube (Wspaniałe dania, Winiarnia Śniadalnia). W 1914 roku otwarto w mieście tak zwaną restaurację samoobsługową: Central-Automat-Reustaurant. Identyczny lokal funkcjonował w Poznaniu od 1903 roku (Automaten Restaurant) ${ }^{21}$.

\subsection{Gospody}

Historyk miasta Franz Idzikowski opisał życie codzienne i świąteczne ówczesnych mieszkańców miasta ${ }^{22}$. W karnawale i w dniach świątecznych bawili się oni w licznych w mieście lokalach z wyszynkiem. W 1937 roku zarejestrowanych było 76 prywatnych jadłodajni, w tym ponad $50 \%$ obiektów było firmowanych polskimi nazwiskami, na przykład: Johann Augustin ${ }^{23}$, Lorenz Buchta, Johann Czech, Georg Dropalla, Georg Michalik, Theodor Nalewaia, Paul Nowak, Emma Scholtissek, Adolf Wrazidlo itp.

Inny rodzaj praktyki nazewniczej uwzględniającej lokalne odmienności przedstawiają nazwy motywowane łatwo dostrzegalnymi wyróżnikami, punktami orientacyjnymi wewnątrz miasta, na przykład: Zur goldenen Kronen (Pod Złotą Koroną), Zur norddeutschen Bierhalle (Pod Północnoniemiecką Piwiarnią). Kilka nazw przywoływało symbole narodowe bądź postaci ze świata polityki: Zum Kurfürst (Pod Księciem Elektorem), Kaiserkrone (Pod Cesarską Koroną), Fürst Bismarck (Pod Księciem Bismarckiem), Katakomben (Katakumby) — nazwa o znaczeniu religijnym może mieć znaczenie metaforyczne, nawiązujące do położenia lokalu poniżej parteru. Takich miejsc było w mieście więcej, na przykład lokal Zunftkeller (Piwnica Cechowa), obecnie nosi nazwę Czardasz. Była ona położona vis-à-vis Izby Rzemieślniczej.

Ciekawa jest motywacja nazwy Zum weissen Pascha (Pod Białym Paszą), nadanej przez właściciela gospody Brunona Glauera na cześć Emina Paszy (właściwe nazwisko: Eduard Schnitzer). Był to lekarz żydowskiego pochodzenia, pracował w tureckim wojsku, przeszedł na islam, przyjął imię Emin i tytuł beja, później paszy, stąd pseudonim Emin Pasza. Wkrótce motywacja nazwy się zatarła i nazwa była kojarzona z właścicielem gospody zwanym „białym paszą”24.

Prawdziwym ewenementem jest historia i trwałość nazwy gospody $W y$ goda w Opolu-Gosławicach. Źródłowo jest ona poświadczona na planie miasta

${ }^{21}$ M. Graf, op. cit., s. 593 .

22 F. Idzikowski, op. cit., s. 197.

23 Jan Augustyn (1882-1940) — działacz społeczny i narodowy, właściciel Gospody Polskiej w Opolu.

${ }^{24}$ F. Kaminsky, Einige Anregungen, „Oberschlesische Heimat” 12, 1916, s. 92-95; zob. też U. Zajączkowska, Emin Pasza - opolanin z urodzenia, Almanach Miejski „Opolanin” 1998, s. 32-33. 
z 1784 roku, gdzie czytamy: „Kretscham für dem Gosslawitzer Thor Wigoda genandt" ${ }^{\prime 25}$. Karczma czynna jest obecnie pod tą samą nazwą. Opole od dawna słynęło z licznych lokali gastronomicznych. Ich liczba w 1937 roku przekraczała 140.

Warto na zakończenie przytoczyć fragment wspomnień Szymona Koszyka (1891-1972), śląskiego działacza narodowego urodzonego w Opolu, świadka tamtych czasów. O opolskich lokalach pisał:

Stały tu również trzy karczmy tuż obok siebie: „Zameczek Odrzański” we frontowej części browaru, restauracja Maushagena i najchętniej przez woźniców odwiedzana gospoda Pragera z zajazdem i stajniami. „Zameczek Odrzański” miał bogatą historię, gdyż był miejscem zebrań opolskiego bractwa kurkowego. Ściany lokalu były upiększone obrazami z zamierzchłej przeszłości. Widzieliśmy tam pochody braci kurkowej w różnowiecznych strojach i mundurach — opolskie bractwo kurkowe istniało od 400 lat [...]. Na Zaodrzu było jeszcze sporo knajp. Wystarczy wymienić restaurację Cymbolka na Blichu (dzisiaj ul. Bonczyka), knajpę Lehrera „Pod Siwkiem” i inne [...]. Heilborn był właścicielem knajpy przy placu Kopernika, wybudowanej po roku 1813 jako oberża „Pod Cesarzem Rosyjskim”. Obecnie znajduje się tam gospoda. W podwórzu były stajnie i do lokalu oprócz żołnierzy uczęszczali również woźnice. Bufet wydawał niskoprocentowe piwo, znacznie tańsze od sprzedawanego w innych lokalach. Żołnierz, otrzymując 22 fenigi dziennego żołdu, nie mógł sobie pozwolić na drogi trunek. Ponadto w knajpie Heilborna można było mówić swobodnie po polsku, podczas gdy w niektórych innych lokalach zaprowadzono już przymus posługiwania się językiem niemieckim. Zwłaszcza wieczorem rozbrzmiewały u Heilborna melodie wesołych pieśni polskich. Policja miejska nie przesiąknięta jeszcze wówczas fanatycznym szowinizmem nie robiła żadnych przeszkód ${ }^{26}$.

Międzywojenne Opole to zatem miasto polskie, którego rzeczywistość językowa była bardzo złożona.

\subsection{Tereny rekreacyjne}

Nie tylko kawiarnie, hotele i restauracje były prawdziwym miejscem rozrywki i wypoczynku. Rozwijający się od połowy XIX wieku przemysł cementowy i budownictwo dewastowały środowisko przyrodnicze. Dlatego też popularne było dla Opola określenie ,białe miasto”. Mieszkańcom brakowało terenów zielonych, parków, ogrodów, skwerów. W 1858 roku prezydent rejencji opolskiej powołał Związek Upiększania Miasta (Oppelner Verschönerungsverein). Tego typu stowarzyszenia działały też w innych miastach państwa pruskiego. Pierwszym ogrodem miejskim, który powstał z inicjatywy tego związku był Park Zamkowy (Schlosspark) przy Zamku Piastowkim (Piastenschloss) ${ }^{27}$. Na jego zapleczu (dziś jest tu amfiteatr) otwarto w 1893 roku malownicze ogrody zamkowe. Wśród wzgórz i mostków przerzucanych przez strumienie pięknymi alejami urządzo-

25 Zob. plan miasta z 1784 roku, [w:] Opole. Dzieje i tradycja..., s. 248.

${ }^{26}$ S. Koszyk, Wspomnienia, [w:] Wspomnienia Opolan, red. W. Kornatowski, K. Malczewski, cz. 1, Warszawa 1960, s. 459.

${ }^{27}$ B. Szczerbanowicz-Pajasek, Parki miejskie - Zamkowy i Ludowy, Almanach Miejski „Opolanin” 2000, s. 49- 51. 
nymi w stylu francuskim spacerowały tłumy mieszkańców i turystów. Atrakcji było wiele, między innymi fontanny z amorkami, sztuczne groty, popiersie Junony — rzymskiej bogini nieba i rodziny. Przy stawku zamkowym (Schlossteich), który zimą zamieniał się w lodowisko, wybudowano Eishaus (Domek Lodowy) z restauracją ogrodową, należący do Towarzystwa Jazdy na Łyżwach (obecnie jest to budynek PTTK z restauracją). Potrzeby rekreacyjne miasta były o wiele większe. W 1910 roku miasto postanowiło wykupić część terenów wyspy Bolko (Bolko Insel), która wówczas była terenem dzikim, bagiennym. W krótkim czasie otwarto tam Volkspark (Park Ludowy), z minizoo, muszlą koncertową, kawiarnią i restauracją. W Opolu powstawały jeszcze inne miejskie kompleksy wypoczynkowe. W Winowie (dziś Opole-Winów) wybudowano w 1928 roku Ogród Miejski (Biergergarten) w stylu japońskim z restauracją: Restaurant Königin Luisenhöhe (Restauracja na Wzgórzu Królowej Luizy).

\section{Centra handlowe i sklepy}

Już od czasów średniowiecza handel i rzemiosło odgrywało dużą rolę w życiu Opola. Około 1300 roku zostały zarejestrowane pierwsze korporacje rzemieślników: piekarzy, rzeźników, krawców i szewców. W 1787 roku Opole było czwartym w kolejności miastem górnośląskim pod względem liczebności cechów $(17)^{28}$. Znalazło to odbicie w liczbie sklepów handlowych różnych branż. Handel stanowił integralną cechę miasta. Był czynnikiem integrującym, sprzyjającym kontaktom różnych warstw i grup społecznych. Miejscem na którym odbywała się wymiana towarów, był Rynek Glówny. Tu budowano kamieniczki z warsztatami rzemieślniczymi i kantorami kupieckimi, stawiano budki garbarskie, jatki rzeźnicze, jatki chlebowe, jatki szewskie. $\mathrm{Z}$ czasem cały handel skupiał się w sklepach i składach lokowanych wzdłuż ścian Rynku i przy ulicach do niego prowadzących. Poza Rynkiem można było handlować w miejscach wskazanych przez magistrat, czyli na targowiskach. Były one wpisane w krajobraz miasta, jego tradycję i folklor.

\subsection{Place targowe}

Poza Rynkiem drugim miejscem targowym był dzisiejszy plac Wolności. W przeszłości zmieniał on swoją nazwę kilkakrotnie. W 1734 roku w źródłach występuje pod nazwą Vieh Markt i Rossmarkt (1750), bo handlowano tu bydłem i końmi, stąd nazwy: Targ Bydlęcy, Targ Koński. Około 1840 roku obok placu postawiono końska fontanne (Rossbrunnen), z czterema głowami końskimi. Na początku $\mathrm{XX}$ wieku, gdy obok placu wybudowano gmach dla władz rejencji, zmieniono jego

${ }^{28}$ A. Steinert, Aus der Geschichte der Ferein Bäckerinnung Oppeln, [w:] Festschrift zur 400-järlich der Ferein Bäckerinnung zu Oppeln, Oppeln 1931, s. 8. 
nazwę na bardziej dostojną: Regierungsplatz (plac Rejencji), a w kilka lat później dokonano kolejnej zmiany na Annabergplatz (plac Góry św. Anny). Nazwę nadano na cześć niemieckich ofiar walk o Górę św. Anny podczas III powstania śląskiego ${ }^{29}$.

Funkcję dużego targowiska pełnił także Mały Rynek. W ciągu dziejów miał on trzy nazwy. Z mapy miasta z 1750 roku dowiadujemy się o istnieniu w tym miejscu placu targowego o nazwie Schweins Markt/Schwarz Viehmarkt, to jest Targ Świński. Obie nazwy niemieckie są synonimiczne, gdzie Schwarz vieh 'trzoda chlewna, dzik'. Od 1832 roku to miejsce przyjęto nazywać Tuch Markt (Targ Płócienny/Targ Sukienny). Miejscem o tradycji kupieckiej był Plac św. Sebastiana, udokumentowany na planie miasta z 1735 roku jako Freier Platz 'niezabudowany plac', z uwagą: „,służący za targ bydlęcy i garncarski”. Kilkanaście lat później (1750) znany jest już pod nazwą Töpfermarkt (Targ Garncarski). Warto dodać, że wyroby garncarskie opolskich rzemieślników, którzy mieszkali przy ul. Töpfergasse, dziś ul. B. Kominka, cieszyły się dużym popytem na Śląsku ${ }^{30}$. Źródła archiwalne potwierdzają istnienie jeszcze innych targowisk. W pobliżu Małego Rynku, przy dzisiejszej ul. Krawieckiej, sprzedawano drób i ptactwo, o czym przekonuje nazwa Gänse Markt (Gęsi Targ). Miał on też oboczną nazwę Hinter Markt (Tylni Targ), to jest położony od tyłu Małego Rynku.

W 1881 roku powstało targowisko Butter Markt (Targ Maślany), na którym sprzedawano nabiał. Wcześniej stały tu dwa młyny, które spłonęły. W dokumentach miejskich utrwalone są też wzmianki o dwóch targach zbożowych: Getreidemarkt, z 1897 i 1912, zlokalizowanych przy Königsstrasse, dziś ul. Plebiscytowa i Nikolaistrasse, dziś ul. Książąt Opolskich. Międzywojenne Opole było prężnym ośrodkiem handlu, o czym przekonują liczne nazwy sklepów różnych branż i targowisk.

\subsection{Domy towarowe i małe sklepy}

Pierwsze opolskie domy towarowe i sklepy stanęły w samym centrum miasta. Najbardziej znane i eleganckie miały właściwe nazwy własne, oddziałujące w bezpośredni sposób na klienta, na przykład:

- Magnetkaufhaus (Dom Towarowy „Magnet”, por. niem. Der Magnet 'magnes' oraz stpol. magnet 'magnes'),

—Modehaus „Schick” (Dom Mody „Szyk”),

- Modehaus „Modern” (Dom Mody „Nowoczesność”),

- Warenhaus Gold (Dom Towarowy Złoto),

- Ehape Warenhaus (Dom Towarowy Ehape — skrót nazwy niejasny).

Inne większe sklepy nie miały nazwy własnej. Do ich nominacji wykorzystywano nazwiska właścicieli, z elementami reklamy, na przykład:

${ }^{29}$ U. Zajączkowska, Na targ do Opola, Almanach Miejski „Opolanin” 1999, s. 51-53; por. też H. Górny, Nazwy własne placów targowych w wybranych miastach Polski - swoistość miejsca i model nazewniczy, „Onomastica” 55, 2011, s. 93-105.

${ }^{30}$ M. Choroś, L. Jarczak, Miejsca wspólne, [w:] Opole. Dzieje i tradycja..., s. 224. 
- Knebel am Annabergplatz (Knebel przy Placu Wolności),

- Das grosse Fachgeschäft für Damen und Kinderbekleidung (Wielki specjalistyczny sklep z odzieżą damską i dziecięcą),

- Letzel \& Grzyb Damenmoden (Moda Damska),

- Geb.[rüder] Sosnowski Damenmoden (Dom Mody Braci Sosnowskich),

- Geb.[rüder] Wrazidlo Josef und Theodor Damen Moden (Dom Mody Braci Wrazidto).

Ten typ nazw był szczególnie rozpowszechniony w nazwach firm rodzinnych. W silnie zgermanizowanym i zdominowanym przez Niemców mieście nazewnictwo polskie odcisnęło na krajobrazie Opola wyraźne piętno. Owa tendencja podyktowana była czynnikami pozajęzykowymi, na przykład związkiem komunikacyjnym między nadawcą a odbiorcą. Zaznaczyła się ona przede wszystkim w branży rzemieślniczej, na przykład fryzjerskiej (por. Georg Bytomski, Josef Gawenda, Josef Stroka), krawiectwie damskim (Albertine Grzewza, Marie Krawietz, Anna Niestroy), krawiectwie męskim (Alois Czech, Amalie Dyballa, Karl Koza), malarstwie (Josef Bienias, Konstantin Leszczyński, Paul Smietana) i szewstwie (Alois Cedzich, Theofil Gawlitza, Franz Malik, Josef Symalla). Wybrane przykłady nazw handlowych pokazują, że polska branża rzemieślnicza była silnie osadzona w tradycji. Potwierdzają to również badania historyczne, stwierdzające, że cechy były ostoją polskości ${ }^{31}$. W okresie międzywojennym przemysł i handel spożywczy $\mathrm{z}$ wolna dźwigały się $\mathrm{z}$ upadku. W mieście działały różne ważne firmy znane ze specjalności i jakości wyrobów, na przykład fabryka likierów i win (Likörfabrik, Wein- und Spirituosenfabrik), ogórków, kwaszonej kapusty (Gurkenkonserven und Sauerkohl), konserw (Konservenfabrik), kawy (Oppelner Kaffe-Rösterei), czekolady (Schokoladengeschäft). Produktów mlecznych dostarczały mleczarnie: Molkerei und Milchgeschäfte, Central Milhof; margaryny firmy: „Malex” - Margarine-Langerungs und Expeditions. Nabiał kupowało się w sklepach pod ogólnie w Prusach znaną nazwą „Der blaue Laden” (Błękitny Sklep), a produkty wegetariańskie kupowało się w ,Vegetabiliach”. Młyny mełły mąkę i kaszę, ryby sprowadzano do sklepów zwanych „,Nordsee”, a jaja magazynowano w chłodniach Eierzentrale Oberschlesien. Zapotrzebowanie na towary kolonialne było niemałe, skoro sprzedawano je w 102 sklepach określanych Lebensmittelgrosshandel, Lebensmittelhandlungen, skupionych w rękach polskich właścicieli, co sugerują ich nazwiska, na przykład Katharina Bias, Anna Bonk, Paul Bulik, Herbert Ciemala, Agnes Chudalla, Heinrich Gasda, Marie Grzesitzek, Anna Kociok, Alfred Lapczina, Vinzent Makiola, Martin Stukowski i inni.

Podsumowując zbiór określeń związanych ze sferą handlową i gospodarczą, można stwierdzić, że sytuują się one na granicy pomiędzy nazwą własną (por. Malex, Nordsee, Vegetabilia) a nazwą pospolitą (por. Lebensmittelhandlung, Schokoladengeschäft). Opole, mimo niewielkiej powierzchni, jaką zajmowało

${ }^{31}$ D. Tomczyk, Studia z dziejów rzemiosła Śląska Opolskiego przed epoka kapitalizmu, Opole 1976, s. 159, 189. 
w tym okresie, było z pewnością aktywnym ośrodkiem rodzimej wytwórczości rzemieślniczej i wymiany handlowej, co otwierało pewne możliwości rozwoju intelektualnego mieszkańców. Tu warto przedstawić grupę nazw związanych z kulturą polską i niemiecką.

\section{Kultura i sztuka}

\subsection{Budowle sakralne}

Początki rozwoju Opola nierozerwalnie są związane z chrześcijaństwem. Wśród najstarszych świątyń wymienia się trzy kościoły: św. Wojciecha i Matki Boskiej Bolesnej, św. Krzyża, św. Trójcy. Jednym z pierwszych był Kościót św. Wojciecha i Matki Boskiej Bolesnej (obecnie pw. Najświętszej Marii Panny). Tradycja wiąże jego początki z pobytem św. Wojciecha w Opolu, gdzie wygłaszał on kazania i chrzcił mieszkańców. Według legendy już w 984 roku wybudowano kaplicę św. Wojciecha. W 1295 roku po raz pierwszy został wymieniony kościół pw. dwóch patronów: św. Wojciecha i Matki Boskiej Bolesnej32. Początki kolegiaty św. Krzyża sięgają XI wieku. Tradycja głosi, że w 1024 roku zostały przywiezione do tej świątyni relikwie Świętego Krzyża. Od 1295 roku kościół stał się parafią dla Opola i okolicznych wsi ${ }^{33}$.

Kościót św. Trójcy to dzieło franciszkanów popieranych przez księcia Bolesława I, którzy wybudowali tę świątynię blisko Zamku Piastowskiego. Kościół został wyświęcony około 1359 roku i stał się największą nekropolią Piastów opolskich. Oprócz trzech wielkich kościołów w obrębie miasta powstawały jeszcze inne niewielkie kaplice i kościoły. Przy Szpitalu św. Aleksego (Alexiushospital) powstała Kaplica św. Aleksego (Alexiuskapelle) czynna do dziś. W 1473 roku wybudowano kościótek św. Barbary (Sankt Barbarae-Kirche) należący do przybyłych do miasta obserwantów (nowa gałąź zakonu franciszkanów założona w XV wieku). Ufundowali go książę opolski Mikołaj i jego żona Magdalena. Po sekularyzacji dóbr zakonnych świątynię sprzedano mieszkańcom wsi Kolanowice, gdzie jest czynna do dziś. W 1667 roku do Opola przybyli jezuici. Początkowo zajęli kościótek św. Aleksego. Pamiątką ich pobytu w pobliżu kościoła św. Wojciecha i Matki Boskiej Bolesnej jest barokowy gmach kolegium jezuickiego (dziś Muzeum Śląska Opolskiego). Jezuici kilkakrotnie podejmowali próby budowy świątyni w pobliżu kolegium. Zgodę na wybudowanie kościoła pw. Najświętszego Serca Pana Jezusa otrzymali pod koniec XIX wieku. Ale kościół ten dopiero w 1930 roku został otwarty dla wiernych w innym miejscu. Epidemia dżumy w 1680 roku, której ofiarą padło $2 / 3$ mieszkańców, przyczyniła się do wybudowania małego kościoła $p w$. św. Sebastiana. Kościół zbudowano na miejscu dawnej

32 E. Kucharz, Ślady kultu św. Wojciecha na opolskiej ziemi, Opole 1997, s. 20.

33 R. Nieszwiec, Drogi do nieba, [w:] Opole Dzieje i tradycja..., s. 184. 
karczmy, w której pojawiła się ta choroba. Święty Sebastian uważany był za patrona chroniącego od morowego powietrza.

W XX wieku w Opolu powstały nowe kościoły: Matki Boskiej Nieustajacej Pomocy (1901), Świętych Apostołów Piotra i Pawła (1925), św. Józefa (1929), Wniebowzięcia NMP (1933) i św. Mikołaja (1934). Społeczność religijna Opola do 1945 roku była zróżnicowana, ale wciąż dominowało wyznanie rzymskokatolickie. Praktyki religijne odbywały się w językach polskim i niemieckim. Wspólnota ewangelicka nie miała swego kościoła. Nabożeństwa odprawiane były gościnnie w kościołach katolickich. Dopiero w 1810 roku ewangelicy otrzymali kościót św. Trójcy (franciszkanów).

Osobną grupę mieszkańców Opola stanowili przybyli tu jeszcze przed lokacją miasta Żydzi. W związku z masowymi prześladowaniami zmieniali swoje miejsce zamieszkania. W XIX i XX wieku liczba wyznawców judaizmu wzrosła. W latach 1840-1842 wybudowali niewielką synagogę (obecnie jest to budynek TVP Opole) i drugą, niezwykle oryginalną, w 1897 roku. W czasach nazistowskich, podczas nocy kryształowej z 9 na 10 października 1938 roku, została ona spalona. Synagogi nie miały nazw.

Spojrzenie na nazwy opolskich świątyń w kontekście historycznym pozwala zauważyć, że nie były one zmieniane z wyjątkiem kościoła św. Wojciecha i Matki Boskiej Bolesnej, który dziś nosi nazwę Najświętszej Marii Panny. W literaturze naukowej znane są różne propozycje klasyfikacji nazw świątyń. Najbardziej rozpowszechnioną jest typologia A. Witkowskiej wyróżniająca kilka kategorii ${ }^{34}$. W obrębie patrociniów opolskich wystąpiły: patrocinia trynitarne: kościót pw. św. Trójcy, patrocinia chrystologiczne: Kościót pw. św. Krzy$\dot{z} a$, Kościót pw. Najświętszego Serca Pana Jezusa, patrocinia maryjne: Kościót pw. Matki Boskiej Bolesnej, Kościót pw. Najświętszej Marii Panny, Kościót pw. Matki Boskiej Bolesnej Nieustajacej Pomocy, patrocinia hagiograficzne: kościót (kaplica) pw. św. Wojciecha, kościót pw. św. Barbary, kościót pw. św. Sebastia$n a$ i inne. W wypadku najstarszego kościoła pw. św. Wojciecha i Matki Boskiej Bolesnej mamy do czynienia z łączeniem funkcji dwóch obiektów na zasadzie styczności przestrzennej.

\subsection{Opole - miasto polskich akcentów i symboli}

Obraz życia kulturalnego miasta byłby niepełny i zniekształcony bez przedstawienia polskich instytucji, organizacji i stowarzyszeń. Język polski, a właściwie gwarę śląską - jak pisał S. Bełza - najczęściej słyszało się w dni targowe, gdy na furmankach przyjeżdżali z okolicznych wsi chłopi, aby sprzedać płody rolne czy wytwory miejskiego rzemiosła. Żywy język polski był zaledwie elementem kolorytu miasta. Trwałymi śladami kreacji polskości są nazwy samorodnych

${ }^{34}$ A. Witkowska, Titulus ecclesiae. Wezwania współczesnych kościołów katedralnych w Polsce, Warszawa 1999, s. 49-58. 
inicjatyw społecznych na rzecz eksponowania polskich tradycji. Oprócz oficjalnego przedstawicielstwa państwa polskiego - Konsulatu Generalnego Rzeczypospolitej Polskiej — działały w mieście różnorodne organizacje, towarzystwa, związki, stowarzyszenia i wydawnictwa, które rozwijały poczucie narodowe u Polaków, walczyły w obronie języka polskiego, kultury, zwyczajów, krzewiły oświatę. Były to czynniki pobudzające kulturalną aktywność Polaków. Już od końca XIX i początków XX wieku ich liczba rosła. Powoływane przez przedstawicieli ludności polskiej, jej właśnie służyły. Były to na przykład: Towarzystwo Polsko-Katolickie (1891), Towarzystwo Oświaty św. Jacka (1917), Towarzystwo Czytelni Ludowych (1917), Towarzystwo Polek (1920) ${ }^{35}$. Pod szczególną opieką działaczy narodowych znajdowała się oświata i edukacja młodzieży. W tym celu zostały powołane stowarzyszenia, na przykład: Towarzystwo Skautów Polskich (1920), Polsko-Katolickie Towarzystwo Szkolne (1923), Zwiazek Akademików Górnoślaskich ,Silesia Superior”, Górnoślaskie Stowarzyszenie Młodzieży Żeńskiej (1924), Zwiazek Polsko-Katolickiej Młodzieży (1926), Związek Główny Harcerstwa Polskiego (1931), Polski Uniwersytet Ludowy (1934).

Polskie życie społeczne skupiało się nie tylko w organizacjach politycznych, takich jak Polska Partia Ludowa, Polsko-Katolicka Partia Górnego Ślaska, lecz przede wszystkim w organizacjach o charakterze narodowym: Związu Polaków w Niemczech (organie zrzeszającym Polaków żyjących w różnych regionach Niemiec), Polskim Komisariacie Plebiscytowym czy Polskim Komitecie Plebiscytowym. Ośrodkami polskiego życia narodowego były redakcje gazet. Jedną z najważniejszych była "Gazeta Polska” (założona w 1890 roku przez Bronisława Koraszewskiego) i jej liczne dodatki: „Rolnik”, „Piast”, „Przyjaciel Domowy”, „Dzwone”, „Słowo Boże”. Od 1911 roku zaczęły wychodzić „Nowiny”, przekształcone od 1920 roku w „Nowiny Codzienne”, wraz z dodatkami: „Piast”, „Żaba”, „Poradnik”. Były one wydawane przez Drukarnię Spótkowa - drukarnię Spótki Wydawniczej „Nowiny”. Możliwości rozwoju polskiego słowa drukowanego były wciąż ograniczone. Na zlecenie bytomskiego Komitetu Plebiscytowego wydawano w języku niemieckim pisma odpierające antypolskie ataki „Der weisse Adler”, „Die Oderwacht, Grenzzeitung”. W tej niesprzyjającej atmosferze rodziły się nowe tytuły: „Przyjaciele Ludu”, „Katolik Trzyrazowy”, „Zdrój”, „Słowo na Śląsku”, „Młody Polak w Niemczech” — dodatek do „Polaka w Niemczech”.

Zwiazek Polaków w Niemczech dużo uwagi poświęcał organizowaniu zespołów artystycznych: teatralnych, muzycznych, chórów, które wchodziły w skład Towarzystwa Teatrów Polskich. Powstały wówczas między innymi: Towarzystwo Śpiewacze „Lutnia”, Związek Kół Śpiewaczych Ślaska Opolskiego oraz chóry: Echo, Jutrzenka, Gwiazda, Dzwonek, Halka, Skowronek.

W Opolu i powiecie opolskim działało kilka kół i klubów sportowych. W 1925 roku powstało Koło Sportowe „Opole”, przekształcone w Klub Sportowy Opole. Elitarny charakter miał Klub Tenisowy Piast, do którego należeli pra-

${ }^{35}$ W. Lesiuk, op. cit., s. 343-372. 
cownicy polskiego konsulatu. Podobny charakter miał Klub Kręglarski „Piast” i Polski Klub Jazdy Konnej. Konsolidacji polskiego życia narodowego wyraźnie sprzyjały różne organizacje w dziedzinie gospodarczej, na przykład Zwiąek Spółdzielni Ślaskich, Spółdzielnia Budowlana, Górnoślaskie Zjednoczenie Rolników, Towarzystwo Rzemieślników Polskich, Polskie Towarzystwo Przemystowe, Towarzystwo Kupców Polskich. Stowarzyszenia gospodarcze były szkołą życia nie tylko gospodarczego, lecz także społeczno-narodowego. Rejestr polskich organizacji i stowarzyszeń nie był bogaty, ale dzięki ich staraniom potrzeby społeczeństwa polskiego były zaspokajane na miarę czasów.

Zasługi wielu z tych towarzystw zostały po wojnie dostatecznie upamiętnione odpowiednimi tablicami informacyjnymi. Są one świadectwem wielowiekowej bytności Polaków mieszkających tu z Niemcami, choć nie było to dobrosąsiedzkie współżycie. Nie pozwalał na to duch ówczesnej epoki.

\subsection{Niemieckie obiekty związane z kulturą i sztuką}

Teatr i kino

Opole przed drugą wojną światową nie miało stałego zespołu teatralnego dysponującego własną siedzibą. Magistrat opolski podpisywał kontrakty z wędrownymi teatrami. Zespoły korzystały z auli ratusza, którą dostosowano do potrzeb artystycznych. Potocznie nosił on nazwę Teatr Miejski (Städisches Theater). Artyści występowali też na terenie prywatnych obiektów, często w pomieszczeniach Hotelu Forma. Pod koniec XIX wieku funkcjonował teatr letni. Na scenach opolskich wystawiano dużo klasyki, a także repertuar francuski, angielski i szwedzki. Dużym zainteresowaniem cieszyła się na przykład sztuka Gabrieli Zapolskiej Tamten. Dystrybucją przedstawień i imprez artystycznych zajmowała się organizacja Christlich Nationale Theaterbewegung (Chrześcijańsko-Narodowy Ruch Teatralny) ${ }^{36}$. W początkowym okresie kultury medialnej sztuka filmowa łączyła się ze sztuką teatralną poprzez nazwę obiektów. W języku niemieckim najstarsze określenie kina to Lichtspieltheater 'teatr gry światła'. W dawnych nazwach polskich kin w użyciu był leksem kinoteatr \|| teatr świetlny (por. nazwę kina w Poznaniu: Teatr Apollo ${ }^{37}$ ). Najstarszym kinem w Opolu był Metropol otwarty w 1907 roku. Drugim kinem było kino Piastowskie \| Piastenlichtspiele, o trzy lata młodsze od Metropolu. W 1939 roku kino Piastenlichtspiele zmieniono na Deli-Theater (skrót Deli utworzono od pełnej nazwy: Deutsche Lichtspiele). Po zakończeniu wojny Deli-Theater zastąpiono polską nazwą Odrodzenie, a w 1958 roku otrzymało nazwę Odra ${ }^{38}$. Największym kinem, otwartym w 1919 roku, było kino Apollo-Theater

${ }^{36}$ D. Schreiber-Kurpiers, Niemiecki krajobraz kulturalny miasta, [w:] Opole. Dzieje i tradycja..., s. 273-281.

${ }^{37}$ M. Graf, op. cit., s. 578.

38 U. Zajączkowska, Z historii opolskiego kina, Almanach Miejski „Opolanin” 2003, s. 41. 
zmienione na Ufa-Theater. Nazwy Apollo i Ufa nawiązywały do nazw berlińskich wytwórni filmowych, przez które były zarządzane.

\section{Stowarzyszenia}

Ludzie zainteresowani kulturą i chcący włączyć się w działalność społeczno-organizacyjną mieli do wyboru wiele różnorakich ofert i możliwości o charakterze edukacyjnym, naukowym, artystycznym, sportowym, religijnym itp.

W sprawach kultury ważne miejsce zajmowało Stowarzyszenie Upiększające (Verschönungs-Verein), utworzone w 1858 roku, stawiające sobie za cel poprawę wyglądu estetycznego miasta. W stowarzyszeniu działali ludzie zafascynowani nowoczesną architekturą i najważniejsi urzędnicy miasta. $\mathrm{Na}$ polu naukowo-edukacyjnym działały trzy różne programowo stowarzyszenia: Naturvissenchafflicher Verein (Stowarzyszenie Przyrodniczo-Naukowe), Verein für schlesischer Altertümer und Kunstdenkmäler (Stowarzyszenie na rzecz Śląskich Starożytności i Zabytków), Philomatie (Filomatia), organizacja popularyzująca wiedzę o regionie, wzorująca się na działających innych Philomatie w różnych miastach śląskich. Stowarzyszenia te współpracowały w staraniach o powołanie Miejskiego Muzeum Przeszłości (Städtisches Altertumsmuseum), które rozpoczęło swoją działalność w 1900 roku w gmachu kolegium jezuickiego, w którym mieści się obecnie Muzeum Śląska Opolskiego. Miłośnicy języka i literatury skupiali się w kilku różnych stowarzyszeniach: Eichendorffverein (Stowarzyszenie Eichendorffa), Verein für Jüdische Geschichte und Literatur (Stowarzyszenie na rzecz Historii i Literatury Żydowskiej), Schutzverband Deutscher Schriftsteller Gau Oberschlesier (Związek Ochrony Niemieckich Pisarzy Okrąg Górny Śląsk), Philologenverein (Towarzystwo Filologiczne), Deutschsprachverein Ortsgr. Oppeln (Niemiecki Związek Językowy Grupa Miejscowa Opole). Istniały w mieście i prowadziły ożywioną działalność organizacje zrzeszające ludzi teatru i muzyki. Miłośnicy teatru mieli do wyboru: Bühnenvolksbund (Ludowy Związek Sceniczny) lub Volkshühne (Scena Ludowa). Melomani skupiali się w Towarzystwie Koncertowym (Konzertverein), Musikverein Oppeln (Towarzystwo Muzyczne Opole) i Männer-Gesang-Verein (Męskie Stowarzyszenie Śpiewacze).

W Opolu już od XIX wieku modne były różnorodne wystawy. Organizowano je w szkołach, w Izbie Rzemieślniczej i hotelu Forma. Wystawy miały stała publiczność, o czym informowały sprawozdania szkolne. Ich organizacją zajmował się Bund für bildende Kunst (Związek Sztuk Pięknych).

\section{Lokalne dzienniki i periodyki}

Niemiecki czytelnik miał do wyboru kilka miejscowych dzienników — organów partii politycznych. Najstarszym, wychodzącym od 1864 roku, był „Oppelner Zeitung”, z dodatkiem „Oppelner Heimatblatt”, należący do Deutsche 
Volkspartei (Niemieckiej Partii Ludowej), konkurujący z „Gazetą Opolską”. Poczytnym dziennikiem był „Oppelner Nachrichten”, który ukazywał się pod nazwą „Wochenblatt für Stadt Und Land i Oppelner Kurier” — pisma były wydawane przez prokatolicką partię Centrum. W latach 1936-1944 ukazywał się OS-Tageszeitung — organ Deutschnationale Volkspartei (Niemiecko-Narodowej Partii Ludowej).

Miasto wydawało ceniony periodyk „Der Oberschlesier” poświęcony między innymi sprawom kultury i krajoznawstwa.

\section{Pomniki}

Kulturową przestrzeń miasta wypełniały też obiekty o charakterze pomnikowym. Według słownikowej definicji pomnikiem jest: „dzieło rzeźbiarskie albo architektoniczno-rzeźbiarskie poświęcone upamiętnianiu zasłużonej osoby lub wydarzenia historycznego; bywa zazwyczaj w kształcie posągu, obelisku, płyty lub rzeźbiarskiej grupy, również kolumny, budowli czy głazu naturalnego, a nawet kopca"39. W wypadku opolskich pomników nie każdy może być zaliczony do tej kategorii. Względy pragmatyczne zdecydowały o wybudowaniu około 1840 roku tak zwanej fontanny końskiej (Rossbrunnen) w kształcie kolumny z czterema końskimi głowami (misami), dostarczającej wody dla koni przy Końskim Targu (Rossmarkt). Wodopój nie był pozbawiony elementów estetycznych. Dominującą funkcję estetyczną pełniły dwie rzeźby: popiersie Junony (Junona - Denkmal) i fontanna bogini Ceres (Monumental — Brunnen). Popiersie Junony — rzymskiej bogini nieba i rodziny - postawiono w parku Zamkowym na wyspie Pasiece (Wilhelmstal) (por. zapisy Forwerch Passeckha 1566). Społeczność miejska wybrała ją za opiekunkę miasta. Moda na upiększanie miasta podyktowała zbudowanie pięknej fontanny bogini Ceres, ozdobionej alegorycznymi rzeźbami. Na cembrowinie basenu postawiono trzy grupy postaci mitologicznych: Ceres i jej córkę Prozerpinę, Neptuna i Glaukosa oraz Herkulesa. Fontanna stanęła w 1907 roku z okazji wystawy rolniczej w Opolu. Stoi na placu Daszyńskiego (Friedrichsplatz) do dziś. Wymowa ideowa pomnika nawiązywała do atutów Opolszczyzny: rolnictwa (Ceres i Prozerpina), flisactwa i żeglugi odrzańskiej (Neptun i Glaukos) oraz wydobywania kopalin z kamieniołomów (Herkules). Większość pomników powstawała z inicjatywy władz pruskich, chcących upamiętnić zasłużone postaci z życia politycznego i zbiorowych bohaterów wojennych. W 1891 roku przy gmachu rejencji opolskiej postawiono pomnik cesarza Wilhelma I (Kaiser Wilhelm-Denkmal). Dwadzieścia lat później przy Dworcu Głównym odsłonięto pomnik kanclerza Niemiec Ottona von Bismarcka (Bismarck Denkmal), zwanego ,żelaznym kanclerzem”, który przyczynił się do zjednoczenia Niemiec. Na początku XX wieku (około 1902 roku) na terenie koszar ustawiono pomnik feldmarszałka Helmutha von Moltkego (Helmuth

39 Stownik języka polskiego, red. W. Doroszewski, t. 6, Warszawa 1964, s. 945-946. 
Moltke-Denkmal), reformatora armii pruskiej. W 1936 roku przy ratuszu ustawiono monument Fryderyka Wielkiego (Standbild Friedrich des Grossen) ${ }^{40}$.

Osobną grupę tworzą pomniki poświęcone niemieckim żołnierzom poległym w czasie pierwszej wojny światowej. W 1924 roku uczczono poległych żołnierzy 63 Pułku Piechoty z Opola (Gefallendenkmal des Oppelner Infanterie - Regiment No 63). Drugi upamiętniał 23 Pułk Piechoty w Rezerwie (Ehrendenkmal des Reserve - Infanterie - Regiments No 23). W 1930 roku przy Poczcie Głównej odsłonięto pomnik poległych pocztowców (Denkmal für die Gefallenen der Post). Ponadto w krajobrazie miasta pojawiały się inne monumenty motywowane symbolami religijnymi, na przykład figura Jana Nepomucena (Nepomuk Statue) czy kapliczka św. Sebastiana (Sebastian Kapelle). Genetycznie były one związane z kultem świętych, mających chronić miasto przed powodzią (św. Nepomucen) i epidemiami (św. Sebastian).

Po 1945 roku niemieckie symbole zostały usunięte. $Z$ jedenastu pomników zachowały się trzy: fontanna bogini Ceres, pomnik poległych pocztowców, poległych żołnierzy 63 Pułku Piechoty, figura św. Nepomucena i św. Sebastiana. Z pomnika Bismarcka zachował się jeden cokół, tak jakby w nawiązaniu do słów Lema: „Burząc pomniki, oszczędzajcie cokoły, zawsze się mogą przydać”41.

\section{Podsumowanie}

Przedstawiony artykuł ma w założeniu charakter interdyscyplinarny, łącząc opis onomastyczny z ustaleniami historycznymi. Praca ta pozostaje także w naturalnym związku z monografią Opole. Dzieje i tradycja (Opole 2011). Cofając się w przeszłość, rekonstruujemy świat dawnych wartości i realiów, ukazujących jak rozwijało się miasto i jakie było widzenie świata minionych pokoleń. Poddane analizie, różnorodne pod względem etymologicznym, motywacyjnym i kompozycyjnym, chrematonimy są swoistą wizy tówką kultury i społeczności tego wieloetnicznego miasta. Wiele obiektów i związanych z nimi nazw z konieczności pozostało poza naszą uwagą.

W pracy starano się jednak pokazać jak najwięcej materiału nazewniczego, zwracając w szczególny sposób uwagę na nazwy polskie. Materiał niemiecki jest ze zrozumiałych powodów przeważający. Skupiając się na tendencjach nazewniczych, dostrzegamy „strukturalne” podobieństwa typów nazw, na przykład Gewerbebank i Bank Ludowy, Katasteramt i Urzad Katastralny. Jeszcze więcej analogii uchwycimy przy analizie czynników motywujących semantykę nazw polskich i niemieckich. W tym kontekście możemy mówić o pewnej uniwersalności wzorców semantyczno-pragmatycznych stosowanych także w innych miastach.

${ }^{40}$ U. Zajączkowska, Dawne pomniki Opola, Almanach Miejski „Opolanin” 1998, s. 34-37; zob. też M. Choroś, Ł. Jarczak, Miejsca wspólne..., s. 232.

${ }^{41}$ Cyt. za: M. Choroś, Ł, Jarczak, Miejsca wspólne..., s. 233. 
Koncentrując się na nazwach niemieckich międzywojennego Opola, należy stwierdzić, że oprócz powszechnych deskrypcji opisowych - złożeń i wieloczłonowych zrostów morfemowych - mamy do czynienia z nazwami skojarzeniowo-informacyjnymi, oddziałującymi na odbiorcę w różny sposób. Takie nominacje zawierały elementy perswazji i reklamy, na przykład Café Residenz, Hotel „Deutsches Haus”, Modehaus „Schick”. Wiele nazw narzucało skojarzenia uwarunkowane społecznie i kulturowo, przekazując treści polityczne (Kaiserkrone, Fürst Bismarck), historyczne (Hotel Germania), literackie (Café Roland), mitologiczne (Apollo Lichtspiele), religijne (Marien-Apotheke, Sankt Peter-Paul Drogerie).

Innym sposobem oddziaływania na odbiorcę były nawiązania do punktów orientacyjnych wewnątrz miasta (Schlosscafé, Bahnhof-Drogerie), symboli (godeł i ikon), na przykład Löwen-Apotheke, Adler-Drogerie; w branży gastronomicznej i rzemieślniczej większość nazw wskazywała na właścicieli obiektów: Gaststätte Johann Struczyna, Kürschnerein Stefan Podsada, Radiohaus Mierzowski.

Wśród chrematonimów opolskich wyróżniają się konstrukcje przyimkowe: Zum Kurfürst, Zur goldenen Kronen; onimy skrócone (skrótowce): Ölex - Deutsche Benzin und Petroleum, Vedag - Vereinigte Dachpappenfabrik, Beku-Beton - und Kunssteinindustrie.

W funkcji nazw odnotowujemy też nazwy geograficzne: Hotel Germania, Havana Haus, Hotel Stadt Breslau. Wszystkie nazwy tworzone są w celu ułatwienia orientacji w okolicy i wyznaczenia ,przestrzeni oswojonej”. Ujmując rzecz najogólniej, są one fragmentem wielowymiarowego bogactwa, które jest charakterystyczną cechą kultury miejskiej.

Nazwy miejskie pozwalają na odtworzenie obrazu społeczności Opola, a była to społeczność mobilna, zakładająca różne instytucje, szpitale, apteki, szkoły, budująca fabryki, upiększająca miasto, zmieniająca jego architekturę i urbanistykę. Opole to miasto polskich i niemieckich związków, towarzystw, czasopism, partii, organizacji społecznych. W mieście działały kina, teatry i muzeum. Dla wszystkich mieszkańców otwarte były parki, lodowiska. Liczba kościołów dowodzi, że społeczeństwo miasta było wspólnotą religijną. Jej szczytnym celem było dążenie do zapewnienia wysokiej rangi swemu miastu. Wśród epitetów odnoszących się do „miasta nad Odrą” przytaczane są określenia specyficznie nacechowane: gród św. Wojciecha, piastowski gród ksiązęcy, miasto urzędników, miasto zielone, zielone miasto mostów, szare miasto (z powodu pylących cementowni), miasto niemieckie, miasto polskie. 


\section{Bibliografia}

Adressbuch der Regierungs-Hauptstadt Oppeln 1902, 1909, 1926, 1937.

Brachmann W., Beyträge zur Apothekengeschichte Schlesien, Würzburg 1966.

Choroś M., Jarczak Ł., Ludzie i historia w nazwach ulic Opola, Opole 2010.

Choroś M., Jarczak Ł., Miejsca wspólne, [w:] Opole. Dzieje i tradycja, red. B. Linek, K. Tarka, U. Zajączkowska, Opole 2011, s. 219-234.

Dolnośląskie apteki i ich nazwy w przekroju historycznym, „Onomastica Slavogermanica” 27, 2008, s. 207-233.

Filipczak J., Zabytki mówia, [w:] Opole. Dzieje i tradycja, red. B. Linek, K. Tarka, U. Zajączkowska, Opole 2011.

Górny H., Nazwy własne placów targowych w wybranych miastach Polski-swoistość miejsca i model nazewniczy, „Onomastica” 55, 2011, s. 93-105.

Graf M., Nazwy budowli i miejsc wydzielonych, [w:] Nazewnictwo geograficzne Poznania, red. Z. Zagórski, Poznań 2008.

Idzikowski F., Opole. Dzieje miasta do 1863 roku, Opole 2002.

Kaczorowski W., Opole jako centralny ośrodek zarzadzania na Górnym Ślasku (w świetle opracowania nadburmistrza dra Augusta Neugebauera), Almanach Miejski „Opolanin” 2000.

Kaczorowski W., Przywilej Apteki Miejskiej w Opolu, Almanach Miejski „Opolanin” 2003, s. 22-24.

Kaminsky F., Einige Anregungen, „Oberschlesische Heimat” 12, 1916, s. 92-95.

Koszyk S., Wspomnienia, [w:] Wspomnienia Opolan, cz. 1, red. W. Kornatowski, K. Malczewski, Warszawa 1960.

Kucharz E., Ślady kultu św. Wojciecha na opolskiej ziemi, Opole 1997.

Lech-Kirstein D., Nazwy osobowe dziewiętnastowiecznych mieszkańców Opola (ze słownikiem etymologicznym nazwisk), Opole 2004.

Lesiuk W., Życie polskie w Opolu w latach 1808-1918, [w:] Opole. Monografia miasta, red. W. Dziewulski, F. Hawranek, Opole 1975, s. 343-372.

Masnyk M., Polski ruch narodowy w Opolu do 1939 roku, [w:] Opole. Dzieje i tradycja, red. B. Linek, K. Tarka, U. Zajączkowska, Opole 2011.

Nieszwiec R., Drogi do nieba, [w:] Opole. Dzieje i tradycja, red. B. Linek, K. Tarka, U. Zajączkowska, Opole 2011.

Opolanie, [w:] Opole. Dzieje i tradycja, red. B. Linek, K. Tarka, U. Zajączkowska, Opole 2011, s. 339-370.

Opole. Dzieje i tradycja, red. B. Linek, K. Tarka, U. Zajączkowska, Opole 2011.

Opole. Monografia miasta, red. W. Dziewulski, F. Hawranek, Opole 1975.

Piast S., Na Śląsku Polskim (wrażenia i spostrzeżenia), Kraków 1890.

Schreiber-Kurpiers D., Niemiecki krajobraz kulturalny miasta, [w:] Opole. Dzieje i tradycja, red. B. Linek, K. Tarka, U. Zajączkowska, Opole 2011, s. 273-281.

Seiffert I., Dolnośląskie apteki i ich nazwy w przekroju historycznym, „Onomastica Slavogermanica" 27, 2008, s. 207-233.

Seiffert I., Nazwy wrocławskich aptek — przeszłość $i$ wspótczesność, [w:] Z najnowszych tendencji nazewniczych, red. R. Łobodzińska, Łask 2005, s. 83-98.

Siwiec A., W sprawie nazw obiektów handlowych: miejsce w klasyfikacji onomastycznej, ustalenia typologiczne, terminologia, [w:] Manuscula linquistica: in honorem Alexandrae Cieślikowa oblata, red. K. Rymut, K. Skowronek, Kraków 2006, s. 423-436. 
Steinert A., Aus der Geschichte der Ferein Bäckerinnung Oppeln, [w:] Festschrift zur 400-järlich der Ferein Bäckerinnung zu Oppeln, Oppeln 1931.

Szczerbanowicz-Pajasek B., Parki miejskie - Zamkowy i Ludowy, Almanach Miejski „Opolanin” 2000, s. 49-51.

Tomczyk D., Studia z dziejów rzemiosła Śląska Opolskiego przed epoka kapitalizmu, Opole 1976.

Witkowska A., Titulus ecclesiae. Wezwania współczesnych kościołów katedralnych w Polsce, Warszawa 1999, s. 49-58.

Zajączkowska U., Dawne pomniki Opola, Almanach Miejski „Opolanin” 1998, s. 34-37.

Zajączkowska U., Emin Pasza — opolanin z urodzenia, Almanach Miejski „Opolanin” 1998, s. 32 33.

Zajączkowska U., Łyżeczka Malkomessa, Almanach Miejski „Opolanin” 2000.

Zajączkowska U., Na targ do Opola, Almanach Miejski „Opolanin” 1999, s. 51-53.

Zajączkowska U., Z historii opolskiego kina, Almanach Miejski „Opolanin” 2003.

\section{The urban space of inter-war Opole from the perspective of proper names}

\section{Summary}

The main aim of the present study is to explore the names of urban sites and interpret them in a historical context. The author tries to examine as many names from the inter-war period as possible, paying particular attention to Polish names. An analysis of Polish and German names has made it possible demonstrate both the structural and the semantic-pragmatic similarity of their types. There are plenty of descriptive types, alongside association-informative names with elements of persuasion and publicity, as well as associations with political, historical, literary or religious content. The analysed urban names make it possible to reconstruct the diversity of the community living in Opole.

Keywords: urban chrematonymy, kinds of chrematonyms, motivation, structure 